\title{
Application of digital tools to enhance tax administration processes
}

\author{
Lyudmila Ripol-Saragosi*, and Ekaterina Gomeleva \\ Rostov State Transport University, Rostov-on-Don, Russia
}

\begin{abstract}
The article discusses approaches to organizing the process of tax administration, reveals the problems and prospects of tax administration through the use of digital tools. The theoretical aspects of tax administration are investigated, the subject and subjects of tax administration are described, the functions and conditions for the implementation of administration processes are revealed. The main problems of tax administration that directly affect tax production are outlined, including: difficult integration of digital tools into the Russian tax space, synchronous interaction of tax administrations on the transfer of necessary data, and others. The main platforms and automated systems used in the practice of tax administration are characterized. Examples of use and statistics of the positive dynamics of tax collection after the introduction of digital resources are given. The ways of overcoming the existing problems, the solution of which will increase the efficiency of tax administration, thereby reduce arrears, increase the collection of tax payments and, as a consequence, increase the revenue side of the state budget.
\end{abstract}

\section{Introduction}

The tax system is one of the main regulators of the economy for the accumulation of income. The main sources of the formation of the revenue side of the budget at all levels of government are tax payments, their receipt is provided by the tax administration system. The completeness and timeliness of tax revenues largely depends on improving the quality of the tax administration procedure. International experience in the field of taxation demonstrates the need for digitalization of tax administration processes. The theoretical and conceptual aspects of tax administration were the subject of scientific research by A.V. Aronov, M.R. Boboev, V.A.Grebennikova, L.I. Goncharenko, T.V. Ignatova, O.L. Mikhaleva, T.A. Terekhova and others. The problems of digitalization of tax administration were investigated by O.L. Mikhaleva, O.S. Skachkova, K.S. Chernous. and others, as well as foreign scientists Eisgruber, T., Le, H. T. D., Nguyen, G. T. C., Bui, M. T., Pereira C., Monteiro A. P., Coelho P., Greil S. The topic of digitalization of tax administration has recently become a trend in the modern economy, so the choice of a research topic is relevant.

\footnotetext{
* Corresponding author: ripboris@ yandex.ru
} 


\section{Study methodology}

The studies carried out show that Russian economists do not have a unified approach to the definition of "Tax Administration". A number of authors believe that tax administration should be understood as the actions of representatives of tax authorities to control compliance with the country's legislation on taxes and fees, i.e. tax control. Pursuant to other researchers, which include the authors of this work, tax administration is a set of measures that contribute to the timeliness and completeness of budget receipts at various levels of taxes and fees, and other mandatory payments. In addition, there are other approaches to the definition of the concept under study. Thus, L.I. Goncharenko believes that the essence of tax administration is deeper than tax control, it is part of the tax management system in the country [8]. The definition of tax administration given by Professor I.A. Maiburov is interesting and sufficiently comprehensive, since this definition has a relationship with the content of tax legislation in force in the country: "The process of managing tax production, implemented by tax and other bodies (tax administrations), which have certain powers of authority in relation to taxpayers and payers of fees" [10]. The studies carried out made it possible to single out the subject of tax administration - this is tax production - strictly specified and legislatively enshrined instruments that determine the algorithm for the fulfillment of taxpayers' obligations and establish the powers of tax and other interested bodies to control and regulate actions to implement tax obligations. Pursuant to the current tax legislation, the tax authorities represent a unified system of control over the observance of the legislation on taxes and fees, for the correctness of calculation, completeness and timeliness of payment (transfer) of all tax payments to the country's budget. All interested bodies are recognized as subjects of tax administration - tax administrations, starting with financial bodies, bodies controlling extra-budgetary funds, internal affairs bodies and customs bodies. The organization of efficient work on tax administration is carried out through continuous enhancement, optimal construction and interaction of all subjects of tax administration. Each body within the subject of tax administration is endowed with certain functions [3]. Thus, the planning function is carried out by financial, tax authorities, as well as bodies of extrabudgetary funds. The tax control function is implemented by all subjects of tax administrations, with the exception of financial authorities. The regulatory function is assigned to financial, tax and customs authorities, as well as bodies of extra-budgetary funds. All of the above subjects of tax administrations, with the exception of financial authorities, perform the function of coercion. The entire system, including administration processes, can be conditionally divided into the following areas: interaction with taxpayers, containing their registration and accounting; conducting tax audits, processing the information received; clarification of the circumstances that led to the emergence of debts; settlement of emerging legal issues of work; operational and analytical work.

The work in the field of providing tax administration for the tax authority is not easy and has its own organizational characteristics. It is a chain of main actions of various directions, but interconnected and representing a single holistic direction of work, as well as contains clearly delineated horizontal and vertical areas of activity, since only in this case tax service specialists will be able to effectively perform their activities $[1,8]$.

A significant position of tax administration is also in the competent attraction and redistribution of financial resources, which precisely determines the relationship between the degree of economic security and the state of other sectors of the economy [2].

Let us highlight the main problems of tax administration, directly affecting tax production.

First, it is possible to highlight the imperfection of tax legislation, namely, its variability and instability. This problem arises due to the fact that the current tax legislation is constantly being adjusted, and this adjustment does not always add specifics, the wording introduced is 
vague and in some cases contradicts previously adopted provisions, which in turn makes it possible for unscrupulous taxpayers to interpret tax legislation in their own way. by illegally evading tax obligations. Consequently, this problem can annually push unscrupulous taxpayers to conceal their real income, which in turn will entail a reduction in tax payments to the budget and an expansion of the shadow sector of the economy [7].

Secondly, the digitalization of tax administration, or rather the difficult integration of digital tools into the Russian tax space may be a problem [4,5]. This problem is associated with the synchronization in space and time of the transfer of the necessary information between tax administrations, as well as taxpayers and tax authorities.

The solution of the above problems will allow raising the level of tax administration, thereby reducing arrears, increasing the collection of tax payments and, as a consequence, increasing the revenue side of the budget and strengthening the economic security of the state. This can be achieved using efficient digital tax administration tools.

\section{Research results}

Activities that minimize tax risks, enhance the efficiency of tax administration and reduce threats to economic security are carried out using various tools, which include both traditional tools, such as the assessment and analysis of the composition and structure of tax payments, tax planning and forecasting, and modern, namely: tax monitoring and digitalization of tax processes.

In addition, it is important to resolve issues of improving the work of the tax service, namely, optimization of tax administration associated with the reforms carried out in the country, as well as the modernization of the tax sphere, which are aimed at overcoming the crisis in the economy.

One of the relevant tools for solving problems of tax administration is automated tax monitoring, which is a system of access to accounting and tax reporting [11]. This tool is aimed at timely identification of inconsistencies in reporting and declared business transactions by the taxpayer. Unfortunately, not all firms can use tax monitoring so far, but only those that meet certain requirements. Pursuant to the current legislation in the field of taxation, the total amount of tax payments for value added tax, excise taxes, corporate income tax and mineral extraction tax payable for the year preceding the year of filing an application by the subject of taxation cannot be less than three hundred million rubles. But it can be assumed that in the further development of tax administration, a similar tax instrument will be introduced, which will be focused on a wider circle of the company.

Considering all of the above, it is necessary in the future to develop an appropriate set of measures aimed at creating mechanisms that will further minimize possible tax risks through tax monitoring [14].

Another important and timely tool of tax administration is the digitalization of tax processes [4]. This digitalization will be expressed in the development and creation of new digital platforms designed to increase tax collection and facilitate tax payment. At the moment, the most widespread and efficient digital platforms are such as the automated control system (ACS): by bank transfer - ASK "VAT-3"; for cash circulation - ASK "KKT".

The digital platform of cash registers ASK "KKT" allows to see retail sales in real time. This program showed the registration of about two million cash registers in 2019, which is a huge breakthrough compared to pre-reform times. Herewith, in practice, there were problems with the introduction of a new procedure for tax accounting using the platform of ASK "KKT", therefore, the algorithm used in the platform needs to be enhanced.

It should also be noted that the installation and maintenance of this platform incurs additional costs for business, in addition, the platform experiences interruptions due to the presence of problems in Internet access, since at present not all territories of the state are 
covered by Internet communications. In this connection, in a number of cases, the financial burden on an economic entity does not become lifting.

Other information platforms, such as the Mandatory Labeling System, the Electronic Dossier on Citizens and the development of the tax program AIS-Tax, will undoubtedly increase the collection of tax payments and make it easier for taxpayers to pay all these payments in the future. But at present, their implementation and application presents some difficulties, both for the tax service and for the taxpayers themselves.

Recently, there has been an active introduction of digital platforms of tax authorities for interaction with organizations in the banking sector. These platforms are built on the basis of distributed ledger technologies, the so-called blockchains, in which it is possible for participants in the process to work with the information of their own node pursuant to the role assigned to it $[6,9,13]$. Last year, a similar approach was used to support businesses and individuals during COVID-19 lockdowns. This allowed credit institutions to promptly check the data on borrowers against state registers administered by the tax service.

Currently, a fourth-generation automated tax information system that is relevant to the external environment is being developed. This task can be solved by updating the work of the Personal Accounts of taxpayers, which will receive notifications about possible tax risks, as well as informing about responsibility for violations of the current tax legislation. The system will function within the framework of one of the most acute and large-scale problems - the lack of understanding by taxpayers of the essence of the tax burden. Since almost every capable citizen of Russia pays taxes, he/she still has little understanding of how important their role is for the entire state.

\section{Discussion of the results}

Agreeing with the opinion of the scientific community $[1,2,4,5,6,9,10,12,13,14]$ on the need to introduce digital tools in tax administration, we believe that the priority measures to overcome the problems of tax administration, as well as to create a favorable business climate in the constituent entities of the Russian Federation, using the possibilities of tax administration through digitalization, should include:

- creating conditions for the widespread use of digital tax platforms through Internet coverage of all settlements;

- development and implementation of digital platforms for small and medium-sized businesses using special tax regimes;

- development and implementation of an information platform that allows to analyze information about taxpayers when they receive income from deposits in organizations of the financial sector of the economy in order to simplify the tax payment procedure;

- enhancement of the platform "Personal account of a taxpayer-individual" in order to simplify the procedure for obtaining tax deductions;

- development and implementation of a digital platform for coordinating actions in space and time between tax administrations and all subjects of tax administration;

- introduction of voice tax advice for all categories of taxpayers.

It should be noted that automated control systems already used in the practice of tax administration, e.g., such as VAT-2 and VAT-3, designed to analyze electronic declarations and automatically identify discrepancies in the data provided, show their efficiency. The analysis of tax revenues allows us to conclude that with the introduction of ASK VAT-2 tax collection increased, and the increase in the percentage on average in 2018 was 13\%, in 2019 the growth showed the greatest dynamics $-16.7 \%$, this is 3.5 trillion rub. receipts, which is 0.5 trillion. rub. more than the same period in 2018. Pursuant to preliminary estimates, in 2020 VAT revenues increased by $26 \%$. Unfortunately, even considering the successes achieved, the VAT gap is $0.6-0.7 \%$ of the planned one. Pursuant to experts, the presented 
digital system contains a large number of unfinished modules, in particular, which should provide control not only for large taxpayers, but also for small businesses.

The proposed measures are fully consistent with the plans for the development of the Federal Tax Service outlined for the near future. Only in the conditions of a high-quality organization of the tax administration process using IT infrastructure and digital tools can the work of both the tax service itself and the efficient functioning of the entire tax system be carried out directly. The country's leadership, with the help of the actions of the tax authorities, was able to form a competent financial and tax policy, thanks to which it was possible to achieve a stable trajectory of economic growth [12]. Experts agree that new information technologies and the formation of a unified information space for tax administration will allow increasing tax revenues without increasing the tax burden.

\section{Conclusion}

The tax authorities represent a single centralized system, thanks to which the fiscal regulation of the state is carried out. Tax payments are the main sources of income for both the federal budget and regional and municipal budgets. At this stage of the development of the tax system and the enhancement of tax administration, there are still problems and shortcomings that prevent the implementation of the planned plans in full. With the elimination of these problems and shortcomings in the future, it will be possible to achieve full compliance with the planned and actual indicators. Digital technologies should become a tool for increasing the efficiency of tax administration. Improving tax administration through the introduction of digital technologies should cover all of its areas: from regulatory support to the modernization of business processes in which all subjects of tax administration are involved.

\section{References}

1. O.L. Mikhaleva, M. Vochozka, Lecture Notes in Networks and Systems 133, 273 (2021)

2. O.L. Mikhaleva, D.V. Syradoev, T.A. Terekhova, Lecture Notes in Networks and Systems 139, 431 (2021)

3. D. Podshivalova, Intertax 49(1), 82 (2021)

4. O.S. Skachkova, Lecture Notes in Networks and Systems 133, 699 (2021)

5. P. Coelho, A.P. Monteiro, C. Pereira, Smart Innovation, Systems and Technologies 209, $186(2021)$

6. H.T.D. Le, M.T. Bui, G.T.C. Nguyen, J. of Asian Finance, Economics and Business 8(1), 823 (2021)

7. E.T. Kassa, J. of Innovation and Entrepreneurship 10(1), 8 (2021)

8. L.I. Goncharenko, Methodology of taxation and tax administration of commercial banks of Russia: dissertation ... Doctor of Economics, Moscow, 472 (2009)

9. Y. Liu, Microprocessors and Microsystems 82,103826 (2021)

10. I.A. Maiburov, Y.B. Ivanov, A.M. Grinkevich, Tomsk State University J. of Economics 47, 5 (2019)

11. K.S. Chernousova, Lecture Notes in Networks and Systems 160, 809 (2021)

12. H. Strauss, T. Fawcett, D. Schutte, J. of Telecommunications and the Digital Economy 8(4), 96 (2020)

13. S. Greil, T. Eisgruber, Intertax 49(1), 53 (2021) 
14. L. Drobyshevskaya, E. Vylegzhanina, V. Grebennikova, E. Mamiy, Lecture Notes in Networks and Systems 136, 95 (2021)

15. T.A. Skvortsova, M.M. Merkulov, M.M. Skorev, N.V. Nesterova, T.V. Kulikova, Lecture Notes in Networks and Systems 87, 1017 (2020) 